\title{
Windthrow Variability in Central Amazonia
}

\author{
Robinson I. Negrón-Juárez ${ }^{1, *}$, Hillary S. Jenkins ${ }^{2}$, Carlos F. M. Raupp $^{3}$, William J. Riley ${ }^{1}$, \\ Lara M. Kueppers ${ }^{1}$, Daniel Magnabosco Marra ${ }^{4,5,6}$, Gabriel H. P. M. Ribeiro ${ }^{6}$, \\ Maria Terezinha F. Monteiro ${ }^{6}$, Luis A. Candido ${ }^{6}$, Jeffrey Q. Chambers ${ }^{1}$ and Niro Higuchi ${ }^{6}$ \\ 1 Lawrence Berkeley National Laboratory, Climate Sciences Department, 1 Cyclotron Rd., MS74R316C, \\ Berkeley, CA 94720, USA; wjriley@lbl.gov (W.J.R.); lmkueppers@lbl.gov (L.M.K.); jchambers@lbl.gov (J.Q.C.) \\ 2 Department of Environmental Studies, University of Redlands, 1200 E Colton Ave, Redlands, CA 92373, \\ USA; hillary_jenkins@redlands.edu \\ 3 Department of Atmospheric Sciences, University of Sao Paulo, Rua do Matao 1226, Sao Paulo, SP 05508-090, \\ Brazil; carlos.raupp@iag.usp.br \\ 4 Institute of Biology, University of Leipzig, Johannisallee 21, 04103 Leipzig, Germany; \\ daniel.marra@uni-leipzig.de \\ 5 Max-Planck-Institute for Biogeochemistry, Hans-Knoell Str. 10, 07745 Jena, Germany \\ 6 Brazil's National Institute for Amazonian Research, Manaus-AM, Brazil, Ave. Andre Araujo 2936, Manaus, \\ AM 69060-97, Brazil; gabrielgiga@gmail.com (G.H.P.M.R.); terezinha.monteiro@gmail.com (M.T.F.M.); \\ luiz.antonio.candido@gmail.com (L.A.C.); higuchi.niro@gmail.com (N.H.) \\ * Correspondence: robinson.inj@lbl.gov; Tel.: +1-510-486-7690
}

Academic Editor: Robert W. Talbot

Received: 16 November 2016; Accepted: 25 January 2017; Published: 4 February 2017

\begin{abstract}
Windthrows are a recurrent disturbance in Amazonia and are an important driver of forest dynamics and carbon storage. In this study, we present for the first time the seasonal and interannual variability of windthrows, focusing on Central Amazonia, and discuss the potential meteorological factors associated with this variability. Landsat images over the 1998-2010 time period were used to detect the occurrence of windthrows, which were identified based on their spectral characteristics and shape. Here, we found that windthrows occurred every year but were more frequent between September and February. Organized convective activity associated with multicell storms embedded in mesoscale convective systems, such as northerly squall lines (that move from northeast to southwest) and southerly squall lines (that move from southwest to northeast) can cause windthrows. We also found that southerly squall lines occurred more frequently than their previously reported $\sim 50$ year interval. At the interannual scale, we did not find an association between El Niño-Southern Oscillation (ENSO) and windthrows.
\end{abstract}

Keywords: windthrows; deep convection; squall lines; Central Amazonia

\section{Introduction}

Windthrows are a recurrent form of tree mortality in the Amazon. They are produced by downbursts [1-3], which are strong descending winds associated with severe convective storms [1-5] that create gaps of uprooted or broken trees [6]. These gaps vary in size from a single tree to thousands of hectares of forest [4,6-8]. Windthrows affect the residence time of woody biomass, which, in turn, affects patterns of productivity and biomass [8,9], floristic composition [10-12], and soil composition [13] in the basin. Recent studies using demographic models have shown that an increase in windthrow frequency promotes a decrease in biomass and leaf area index in Central Amazonia [14]. These results suggests that windthrows may have cascading effects and represent an important and overlooked source of uncertainty in climate predictions, especially given more intense rainfall events are expected to occur in the future [15]. Though efforts have been made to understand 
the spatial variability of windthrows in the Amazon [3-5,7], studies addressing the temporal variability of windthrows are limited $[8,16]$.

One source of large windthrows in Amazonia is the long-lived squall lines that are generated along the northern coast of South America and propagate inland. Squall lines are mesoscale convective systems (MCSs) in which the convective cells are strongly aligned on the leading edge of the squall, creating a large length-to-width ratio for this type of convective organization [17]. These squall lines can produce downbursts with wind velocities strong enough to yield large blowdowns [1]. Squall lines that originate along the northern coast of South America are the most common type of squall line in Amazonia. They result from diurnally forced deep convection associated with the sea breeze circulation [17]. Under a suitable synoptic-scale flow regime, these $24-48 \mathrm{~h}$ systems can penetrate deep into the continent, propagating southwestward with speeds of up to $16 \mathrm{~m} \cdot \mathrm{s}^{-1}$ for a few thousand kilometers [18-20]. In this study, we refer to these squall lines as Northerly Squall Lines (NSLs). NSLs are closely linked to the occurrence of stronger and deeper than usual low level easterly jets along the northern coast of South America [20]. These easterly jets create a deep low level vertical shear perpendicular to the squall line, which is responsible for the intensity and longevity of mesoscale convective systems [21]. NSLs (that penetrate $>400 \mathrm{~km}$ across the continent) represent $20 \%$ of all squall lines that occur in the basin. They generally occur every two days, but are most frequent between April and June and least frequent between October and November [19,22].

Squall lines can also be produced in the southern portion of the basin $[3,23,24]$ and sometimes propagate northeastward across the entire Amazon basin. Here, we refer to these squall lines as Southerly Squall Lines (SSLs). Between the 16 and 18 January 2005, a severe SSL originated in southwest Amazonia and propagated northeastward to the northern coast of South America over a $48 \mathrm{~h}$ period. This event was first studied by Alonso and Saraiva [25], who identified this system as a squall line. By using radar imagery, the authors identified a cluster of deep convective cells that created a continuous band of high cloud tops on the systems' leading edge and a region of lower precipitation on the southern side of the squall, which represents a trailing region of stratiform precipitation. Between this precipitation and the front end of the storm is a transition zone with little radar reflectivity. This region is associated with a cold pool induced surface meso-high. They also analyzed the thermodynamic and dynamic aspects of this squall system by analyzing soundings and hodographs from the 18 of January-the date when the system passed through the city of Manaus. All the characteristic aspects of severe and long-lived squall lines, such as a large atmospheric thermodynamic buoyancy instability and a strong and deep low-level vertical shear, have been identified in this event. The January 2005 SSL was responsible for windthrows in Central Amazonia [3]. Thus, SSLs constitute another source of windthrows in the Amazon basin. However, SSLs have not been extensively studied in Amazonia, perhaps due to the idea that they have a very low return period [23].

Previous studies have shown that large windthrows in the Amazon are associated with squall lines [1,3], but whether the El Niño - Southern Oscillation (ENSO) [26] or seasonal rainfall are related to the occurrence of windthrows in the Amazon is unknown. Studying the frequency of windthrow occurrence is key to understanding the atmospheric conditions that produce these events. This understanding will also enhance the accuracy of Earth System Models (ESMs), given that windthrow related tree mortality is not currently represented in ESMs [27]. A stronger understanding of the physical mechanisms that control windthrow formation as well their persistence and frequency in a changing climate is clearly needed.

Our research questions are:

1. What is the seasonal and interannual variability of windthrows?

2. Are windthrows associated with ENSO?

The temporal variability of windthrows in the Amazon is currently unknown. This study therefore represents the first record of windthrow variability in the Amazon. As a pioneering study, we focus on the generalities of atmospheric events responsible for the variability of windthrows. 


\section{Data and Methods}

\subsection{Study Area}

The study area was located in Central Amazonia covered by Landsat imagery P231/R062 $\left(3.4 \times 10^{4} \mathrm{~km}^{2}\right.$, Figure 1). This area encompasses the Tropical Silviculture Experimental Station (EEST, per its acronym in Portuguese) located at $\left(2.45^{\circ}-2.66^{\circ} \mathrm{S}, 60.02^{\circ}-60.32^{\circ} \mathrm{W}\right), 53 \mathrm{~km}$ north of the city of Manaus, Amazonas State, Brazil, and contains 21,000 ha, most of which is old-growth forest [27]. Landforms in the EEST include plateaus (90-105 meters above sea level, $\mathrm{m}$ a.s.l.) and small valleys (45-55 m a.s.1.) [28,29]. Soils on the plateaus are generally of a clay texture, while soils from the upper slopes are sandy clays. Soils on the lower slopes are loamy sands, and soils in the valleys are sand dominated [28]. Soil texture, organic matter content, soil moisture, soil $\mathrm{pH}$ and soil $\mathrm{C}$ and $\mathrm{N}$ concentrations vary significantly with elevation along topographic gradients in the Central Amazon [30]. The forest maintains a high diversity of tree species [31-33] with a mean canopy height of $\sim 30 \mathrm{~m}$ with the tallest trees exceeding $40 \mathrm{~m}$ [34]. Lecythidaceae, Sapotaceae, Fabaceae, Chrysobalanaceae, Burseraceae, Annonaceae, Moraceae, and Euphorbiaceae are the most abundant botanical families in the EEST [31-33,35]. Some of the most common species that characterize the area are Dinizia excelsa Ducke (angelim-pedra), Eschweilera coriacea (DC) S.A. Mori (mata matá), Protium apiculatum Swart (breu-vermelho), Scleronema micranthum (Ducke) Ducke (cardeiro) and Micrandropsis scleroxylon (W.A. Rodrigues) W.A. Rodrigues (piãozinho) [31,35,36]. The mean density of stems above $10 \mathrm{~cm} \mathrm{DBH}$ (diameter at breast height, $1.3 \mathrm{~m}$ ) is $584.3 \pm 25.9$ trees $^{-h^{-1}}$ [35,37], with $^{-3}$ $93 \%$ of stems bellow $40 \mathrm{~cm}$ in $\mathrm{DBH}$ [38] and the annual mortality (down and standing trees) based on analysis of forest inventory plot data is 8.7 trees $\cdot \mathrm{ha}^{-1}$ [32].
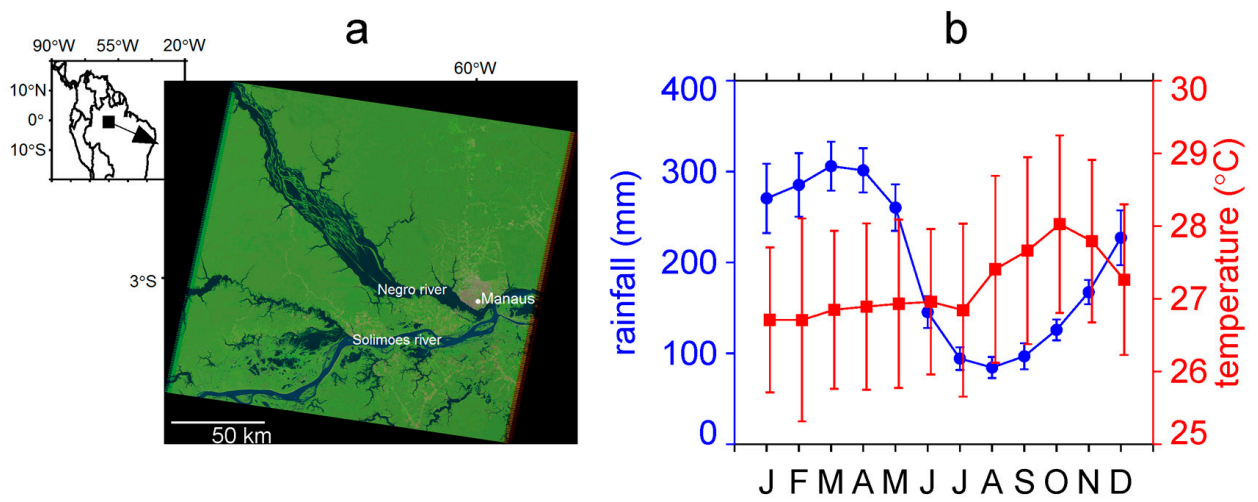

Figure 1. Study area. (a) Landsat scene (P231R062) of our study area-a $3.4 \times 10^{4} \mathrm{~km}^{2}$ region in Central Amazon; (b) climatology (base period 1971-2000) of rainfall and temperature over our study area. The climatology was obtained using rainfall data from the Global Precipitation Climatological Centre and temperature data from the Climatic Research Unit (see text for details).

\subsection{Meteorological Data}

We characterized the current climatology in Central Amazonia based on the period 1971-2000 [39] using the Global Precipitation Climatological Centre data Reanalysis version 7 for rainfall [40] and the Climatic Research Unit Time series v3.23 data [41] for temperature. Both data sets are available at $0.5^{\circ}$ horizontal resolution on a monthly basis. Our study area is characterized by a mean annual temperature of $27^{\circ} \mathrm{C}$ and mean annual rainfall of $2365 \mathrm{~mm}$ with the dry season (rainfall $<100 \mathrm{~mm} \cdot \mathrm{month}^{-1}$, [42]) falling between July and September (Figure 1).

The Tropical Rainfall Measuring Mission (TRMM) data [43] version 7 were also used in this study at monthly (3B43) and $3 \mathrm{~h}$ temporal resolution (3B42) from 1998 to 2010. These gridded data are at a $0.25^{\circ} \times 0.25^{\circ}$ spatial resolution from $50^{\circ}$ South to $50^{\circ}$ North latitude. The $3 B 42$ estimates are a combination of microwave and infrared precipitation estimates calibrated and merged with 
observations, which are then rescaled to a monthly time step to produce the 3B43 data [43]. TRMM 3B43 and TRMM 3B42 will be referred to hereafter as TRMMmo and TRMM3h, respectively.

We also used reanalysis data from the National Centers for Environmental Prediction (NCEP) [44] to study the SSLs.

\subsection{Windthrow Identification}

The long time series of Landsat imagery ( $30 \mathrm{~m}$ horizontal resolution) is appropriate to study the temporal variability of windthrows. Thematic Mapper images from Landsat 5 and Landsat 7 satellites (L5 and L7, respectively) are available in the archive of the Google Earth Engine (GEE) [45]. Fifty-nine images from September 1998 through August 2010 were analyzed in this study. Most of the images used had less than $30 \%$ cloud cover and images from June to November were the most common images analyzed (Figure 2), a pattern that coincides with the beginning and end of the dry season (Figure 1) and therefore less cloud cover. Figure 2 also shows the difficulty in analyzing the traditional four seasons (DJF, MAM, JJA, SON) in Central Amazonia using Landsat imagery. We have therefore grouped images from the rainy (SONDJF) and dry (MAMJJA) seasons. Although there may be some uncertainty surrounding the seasonal assignment of a windthrow, the occurrence of the windthrow is clearly identified in all cases.

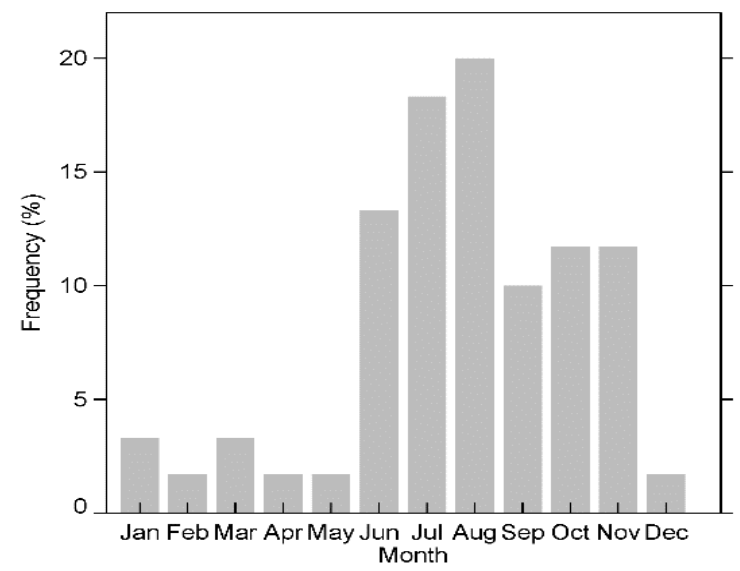

Figure 2. Percent of images with less than 30\% cloud cover analyzed per month from September 1998 to August 2010.

To identify windthrows, a spectral mixture analysis (SMA) [46,47] was applied to the Landsat images. SMA quantifies the per pixel fraction of endmembers which sums to match the full pixel spectrum of the image [46]. Image-derived endmembers of green (photosynthetic) vegetation (GV), non-photosynthetic vegetation (NPV), and shade were used. A shade endmember was included to account for effects related to view angle, topography, shading, and shadows from clouds. Endmembers for GV was green cecropia and for shade a lake in our Landsat scene as shown in Chapter 7 in Adams and Gillespie [48]. In windthrow areas, a large increase in bare wood from downed trees is exposed to the satellite sensor, yielding a high mid-infrared reflectance (band 5, 1550-1750 nm, in Landsat 5 and Landsat 7) that lasts for about a year [3,4]. The fractions of GV and NPV were then normalized without shade [48] as GV/(GV + NPV) and NPV/(GV + NPV). Our goal was to detect windthrows, and applying SMA to the DN (digital number) of the Landsat data was reasonable given SMA in Amazon forests does not produce significantly different results using DN or atmospherically corrected images $[48,49]$. A windthrow area was determined from the polygon containing the windthrow using available tools in the GEE platform. Only windthrows located $>2 \mathrm{~km}$ away from urban areas and larger than 5 ha were considered in our analysis. Examples of windthrows over our study area have been published in our previous studies (e.g., Figure 2 in [3] and Figure S5 in [8]). 


\subsection{Dating of Windthrows}

Windthrows were identified by their fan-shaped form [4] and high NPV values, as we have shown in previous studies $[3,7,8]$. We visually inspected each image that preceded a windthrow image to ensure that the prior image showed undisturbed forest. We chose to study the seasonal and annual variability of windthrows because of the availability of Landsat images and the variability of rainfall over these time periods.

Annually. We assigned the timing of windthrows to the hydrological year (HY, September to August) in which they most likely occurred. We used the date of the Landsat image in which a windthrow first appeared to identify the windthrow date, although the windthrow could have occurred at any time between the previous and current Landsat image, introducing uncertainty in the date assignment. For instance, windthrows that appeared for the first time in a 10 September 2009, image were included in the HY2009-2010 year (September 2009-August 2010) although there is a chance these windthrows could have occurred between this image and the previous one (dated 25 August 2009). This creates a 16-day uncertainty in the windthrow date (26 August-10 September) that spans two hydrological years (HY2008-2009 ending on 31 August and HY2009-2010 beginning on 1 September). Of the 199 windthrows identified in Landsat images, we found that 68 could have been dated to their previous hydrological year (referred to here as $\mathrm{HYb}$ ). Eighteen of these cases occurred in HY2006-2007, 13 in HY2007-2008, 10 each in HYs2001-2002 and 2005-2006, seven in HY1998-1999, five in HY1999-2000, three in HY2003-2004, and one each in HYs2000-2001 and 2009-2010.

Seasonally. To study windthrow seasonality, we examined rainy season (SONDJF, months are identified by their first letter) and dry season (MAMJJA) windthrow frequency. A larger dating uncertainty occurred with rainy season (SONDJF) images because of cloud cover and image availability over this time period. On average, $2 \pm 1$ (mean \pm standard deviation) windthrows could have occurred in the previous season (MAMJJA), except in the hydrological years 2001-2002, 2003-2004, 2005-2006, 2006-2007, and 2007-2008 when $12 \pm 3$ windthrows that could have occurred in the previous season. A shorter time scale (e.g., monthly rather than seasonal) is difficult to analyze due to image availability and an abundance of cloud cover.

Another source of uncertainty that makes windthrow dating difficult is the fact that the edge overlap of the Landsat tiles varies with time. If a windthrow for a given year appeared on the border of an image, but this same border did not appear in subsequent images then that windthrow was excluded from our analysis.

\subsection{ENSO Years}

Sea surface temperature (SST) data [50] is used to examine anomalies in the Pacific region $\left(5^{\circ} \mathrm{N}-5^{\circ} \mathrm{S}, 120^{\circ} \mathrm{W}-170^{\circ} \mathrm{W}\right.$, the Niño 3.4 region) related to ENSO (positive values indicate warm El Niño periods and negative values indicate cold La Niña periods). A SST deviation $\geq 0.5^{\circ} \mathrm{C}$ is used by the Climatic Prediction Center/National Oceanic and Atmospheric Administration to define the occurrence of an El Niño or La Niña. The list of ENSO years as well as further details are available at [51]. In this study, we used this list to identify ENSO years in our time series.

\section{Results}

Figure 3 shows the occurrence of windthrows over the study area from 1998 to 2010. A few windthrows appeared within the black background of the image; these were related to changes in the Landsat tile cover areas. Populated areas were not considered in our analysis and therefore no windthrows were mapped in these areas. For instance, the southeastern corner of the Landsat image has high anthropogenic activity and therefore few windthrows were mapped here. The histogram of windthrow sizes was skewed to the left indicating that the smallest windthrows were the most frequent, which is consistent with previous studies [7,8]. Windthrows in bins (data in intervals) of 20, 40 , and 60 ha represented $42 \%, 28 \%$, and $12 \%$ of windthrows events, respectively. 


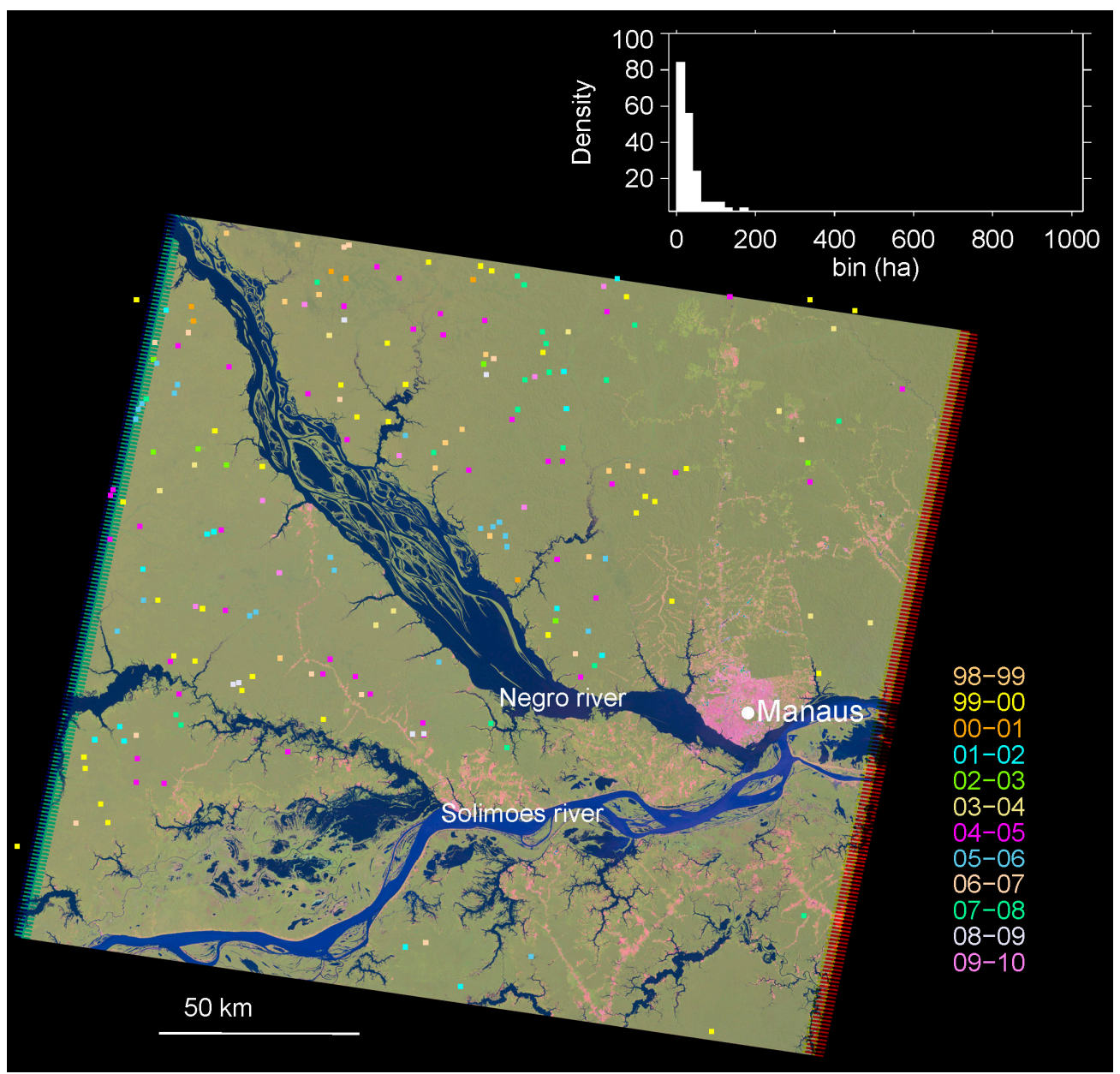

Figure 3. The spatial occurrence of windthrows in the study region over the period 1998-2010. The histogram of size frequency is shown in the top inset. The background image (L5 from 4 August 2007 was selected due to its free cloud cover condition) is shown for spatial context: blue represents water bodies, pink and light green represent anthropogenic areas, and dark green represents oldgrowth forest. Squares represent the centroid of windthrows with the color representing the year of their occurrence as defined in the figure legend.

Our results showed (Figure 4) a high seasonal variability of windthrows, but, in general, the rainy season (SONDJF) had a greater number of windthrows than the dry season (MAMJJA). This pattern is similar for the HYb case (results not shown). For the MAMJJA 2002-2003 and SONDJF 2008-2009 seasons, the number of events dated was zero. We found that $75 \%$ of windthrows occurred in the rainy season and $25 \%$ in the dry season. We also considered the seasonal dating uncertainty when a given windthrow could have occurred in the previous season. If we account for these cases, only $59 \%$ of windthrows occurred during the rainy season. The seasonal occurrence of windthrows observed in our data agrees with previous studies that have dated windthrows $[3,16]$. Abundant cloud cover made it difficult to date windthrows during the rainy season (SONDJF), particularly during the 2007-2008 La Niña year when 18 windthrows could have occurred in the previous season. 


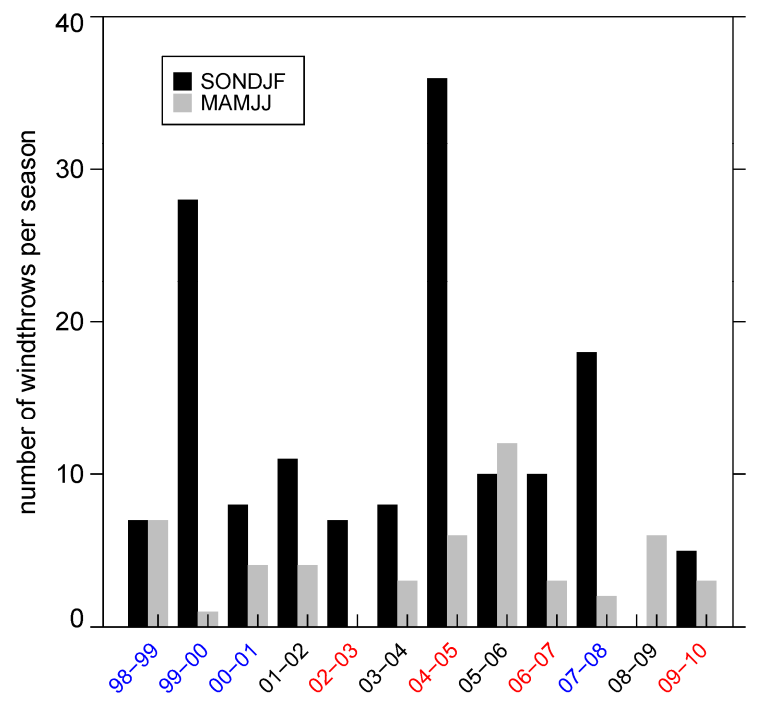

Figure 4. Seasonal occurrence of windthrows in the study area. La Niña years highlighted in blue, El Niño years highlighted in red. Bars in black represent the September to February time period and bars in gray represents the March to July time period.

The number of windthrows that occur annually mostly covaries with annual rainfall. However, a few key mismatches (Figure 5) prevent a high coefficient of determination $\left(r^{2}<0.1 p<0.001\right)$ between windthrows and rainfall for both the HY and HYb cases. HY2004-2005 and HY2008-2009 presented the lowest [39] and highest [52] rainfall amounts, respectively (the pattern was similar for the HYb case), and, rather counterintuitively, these years had the highest (HY2004-2005) and lowest (HY2008-2009) occurrence of windthrows. When these two years were omitted, the data showed a much stronger relationship between rainfall and windthrows in the HY case $\left(r^{2}=0.7, p<0.001\right)$. Interestingly, this relationship was not captured in the HYb case $\left(r^{2}<0.1\right)$, revealing the importance of properly dating windthrows. On average, the annual number of studied windthrows was $16 \pm 10$ events (mean \pm SD).

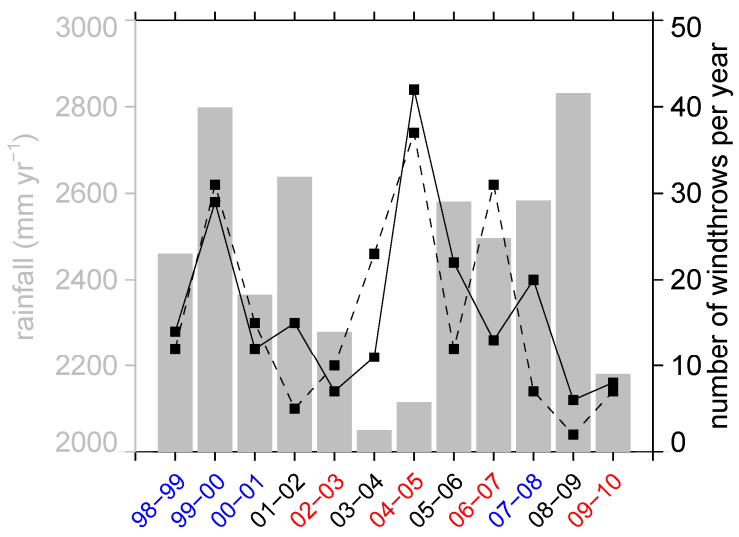

Figure 5. Annual occurrence of windthrow events (solid and dashed lines) over hydrological years 1998-1999 to 2009-2010 plotted against annual rainfall (gray bars). Rainfall data taken from Tropical Rainfall Measuring Mission 3B43 (TRMMmo) as described in Section 2.2. Rainfall data and windthrows correspond to the area covered by the Landsat tile P231/R062 as described in Section 2.1. HY (Hydrological year) case plotted in the solid line and HYb plotted in the dashed line. La Niña years highlighted in blue, El Niño years highlighted in red.

In the HY2004-2005, a large number of windthrows were observed even though that year contained the lowest rainfall amount. In this year, the large occurrence of windthrows was produced 
by a SSL that crossed the Amazon basin in January of 2005 producing a large number of windthrows in the Manaus region [3]. However, only four NSLs [17] were recorded that month, the smallest number recorded during any month in 2005 [53].

We identified several SSLs (November and December 1998, January and February 2002, January 2004 and January 2005) using the TRMM3h data (Figure 6). Interestingly, these years also contain a high number of windthrows, particularly HY1998-1999, a La Niña year. A peak in windthrow frequency was also observed during HY1999-2000, another La Niña year. The synoptic features associated with the November 1998 SSL event are shown in Figures 7 and 8. These circulation features are regarded as characteristic of the environment in which the southerly squall lines form. The SSLs that occurred in 2002, 2004, and 2005 (Figure 6) exhibit similar synoptic features to those of the 1998 event and have therefore been omitted.

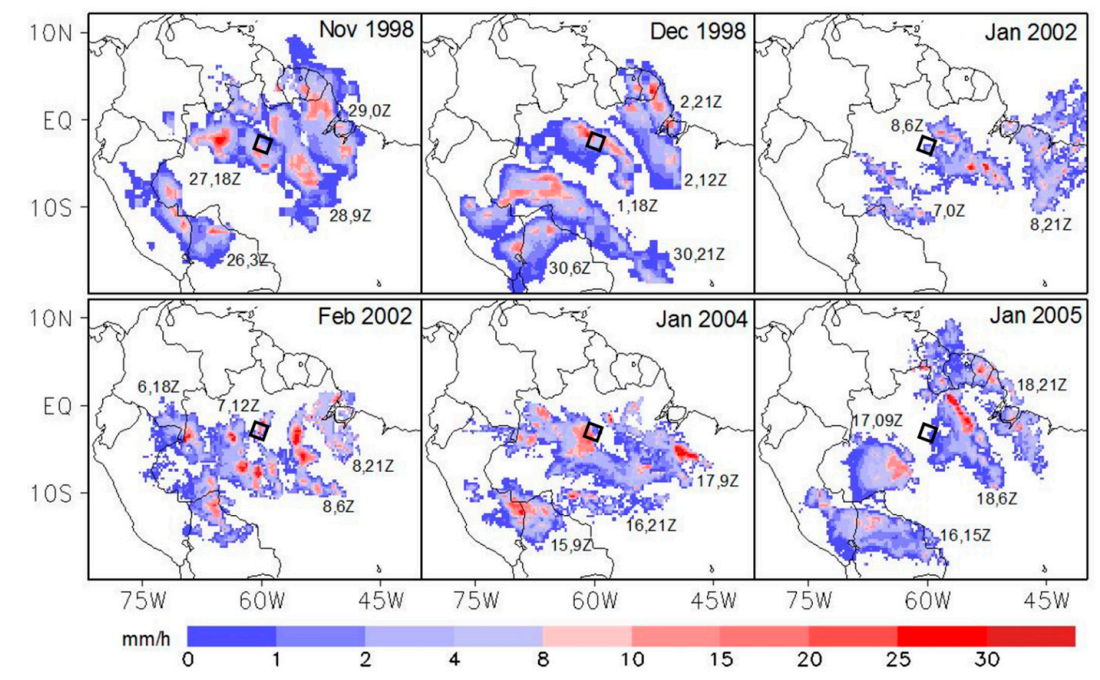

Figure 6. The position of southerly squall lines in the Amazon at different times obtained using TRMM3h data. The Landsat tile of the study area is also shown. The numbers in the Figures (e.g., 6, $18 \mathrm{Z}$ ) indicate the day of the month, and the hour (in Coordinate Universal Time, Z).

a

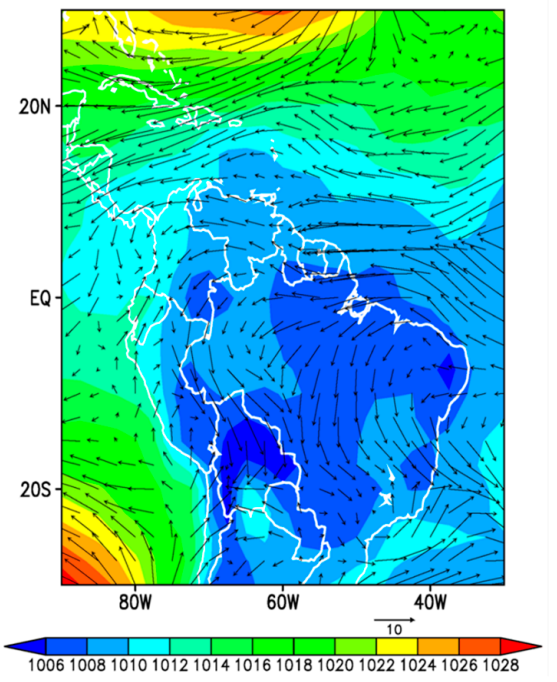

b

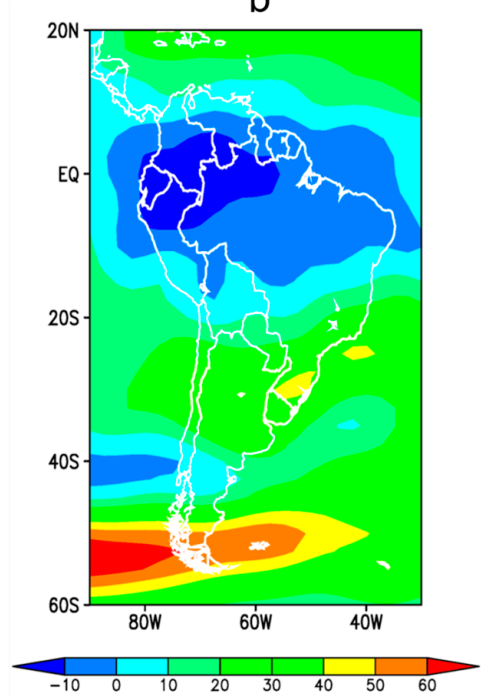

Figure 7. (a) Reduced sea level pressure (shaded, in millibars) and horizontal wind fields (arrows) at the $850 \mathrm{hPa}$ pressure level. (b) Zonal wind field (m/s) at $200 \mathrm{hPa}$ pressure level. The date corresponds to the onset of the SSL on 30 November 1998 at 18 UTC. Data is from the The National Centers for Environmental Prediction (NCEP) Reanalysis data [44]. 
a

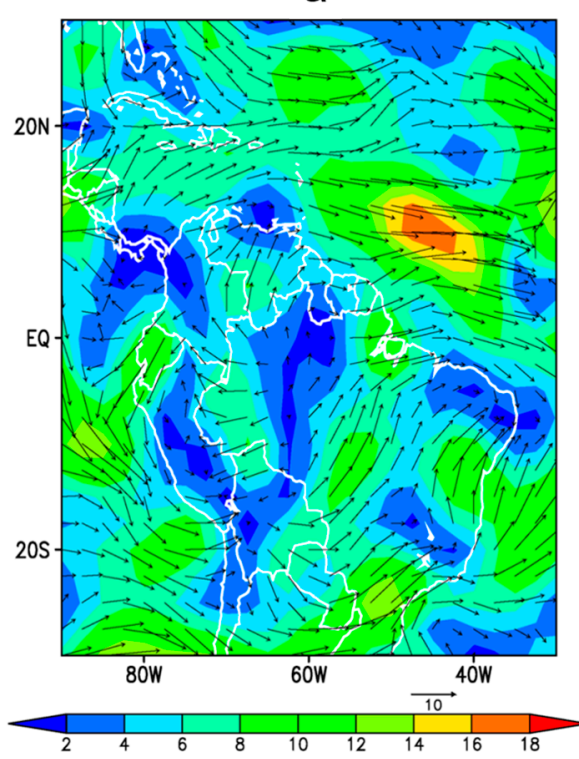

$\mathrm{b}$

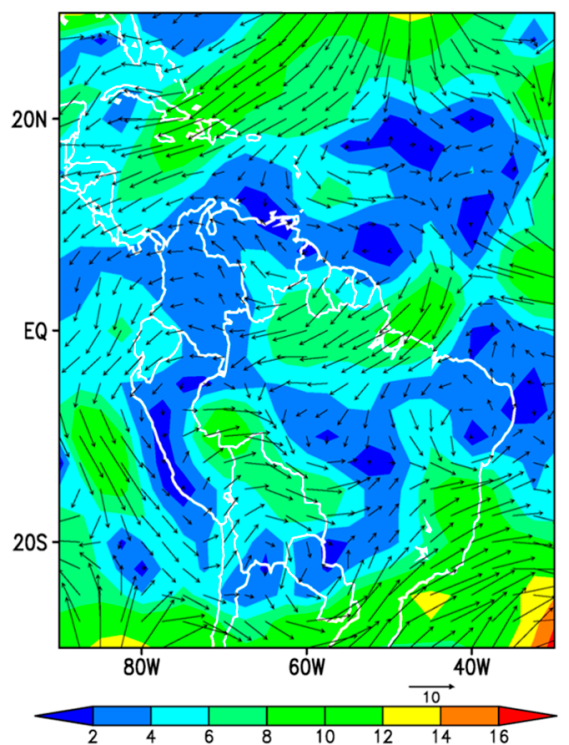

Figure 8. (a) Lower troposphere horizontal wind vertical shear estimated from the difference between the horizontal wind at $600 \mathrm{hPa}$ and $850 \mathrm{hPa}$ pressure levels. The shaded areas indicate the wind shear magnitude (m/s). (b) Horizontal wind field at the $600 \mathrm{hPa}$ pressure level. The shaded areas indicate the wind magnitude (m/s). The date corresponds to the onset time of the November 1998 SSL. The National Centers for Environmental Prediction (NCEP) Reanalysis data [44] were used to plot the displayed meteorological fields.

Figure 7a shows a convergence zone extending from the Southwestern Amazon coupled with a cold front that extends to Southeastern Brazil as well as an easterly flow over the equatorial Atlantic Ocean associated with the subtropical high. This easterly flow is deflected by the Andes Mountain resulting in a northerly low level jet (due to the potential vorticity conservation) toward the convergence zone, creating a moisture channel linking this flow back to the southern equatorial Atlantic Ocean, the southeastern Amazon basin and southeastern Brazil. All of these features characterize the typical synoptic-scale pattern associated with a cold front that reaches southeastern Brazil during the austral summer and yields an organized northwest-southeast oriented band of deep convection in southwestern Amazonia. When these features remain stationary for at least four days, they become the South Atlantic Convergence Zone (SACZ) [54,55]. However, the SACZ can also be triggered by the subtropical jet stream ( at $30^{\circ} \mathrm{S}$, Figure $\left.7 \mathrm{~b}\right)$ which occurs as a consequence of the enhancement of the upper troposphere anti-cyclonic circulation over the Amazon and Central Brazil [56].

An important dynamical feature responsible for the severity, organization and longevity of squall lines is a deep and moderate-to-strong low-level vertical shear that occurs perpendicular to the squall line and controls the ambient flow in which the squall systems are embedded. This essential feature is present in all SSL cases analyzed (represented in Figure 8a). The low-level shear of the wind is oriented northeastward. Thus, the northeastward propagation of the SSL systems can be explained by the lower-troposphere wind shear displayed in Figure 8a. The uniformity of the lower-troposphere vertical shear along the squall line region displayed in Figure 8a may explain the high degree of organization of the convective cells in a band on 1 December 1998. The SSL cases showing less convective cell organization are associated with a less uniform low-level shear along the squall line, as occurred with the SSLs in January and February, 2002.

Figures $7 \mathrm{a}$ and $8 \mathrm{~b}$ also show that the SW-NE directed low-level vertical wind shear appears to be a result of the large-scale wind regime over the Amazon, which is associated with a cold front that extends to southeast Brazil. This regime is characterized by northwesterly winds in the lower troposphere, which transport significant moisture toward the NW-SE oriented convergence zone, and a 
westerly regime in the mid-troposphere (Figure 8b). It is also evident that the mid-troposphere westerly wind regime over the Amazon region is associated with the mid-troposphere cyclonic circulation, which provides dynamical support for development of the surface cyclonic circulation associated with the cold front (Figure 8b). In cases when the mid-troposphere westerly flow over the South Amazon is weak, the shear is directed northward and the propagation of the SSL is also nearly northward (figures not shown).

\section{Discussion}

In general, we found that the rainy season (SONDJF) has a higher occurrence of windthrows than the dry season (MAMJJA), a pattern concurrent with extreme convection (highest in OND, lowest in AMJ) in Central Amazonia [57]. Seasonal rainfall is regulated by the South American Monsoon System (SAMS) [58-60]. The southern hemisphere sector of tropical South America exhibits strong seasonal variation in precipitation and large-scale circulation even though such circulation patterns are not totally reversed as is typical of Northern Hemisphere monsoon systems. The circulation pattern of the SAMS is not fully reversed because the zonal asymmetries of the dry-season circulation are rather weak and, consequently, the mean winter circulation is strongly dominated by the zonally symmetric component of the general circulation. Therefore, although the zonal asymmetry of the large-scale circulation during the dry season is rather weak and thus overwhelmed by the zonally symmetric Hadley circulation, the strong zonal asymmetries characterizing the large-scale circulation during the wet season make it possible to extract a canonical pattern of seasonal variation of the tropical South American large-scale flow that resembles a typical monsoon system. da Silva and Carvalho [61] have defined an Empirical Orthogonal Functions (EOF) based index to characterize the mechanism associated with the intraseasonal and interannual variability of the SAMS. The SAMS has been a topic of intense research throughout the last decade, exhibiting significant inter-annual, intra-seasonal, synoptic and diurnal variability [58,62].

The SAMS has a strong seasonal signal which produces large amounts of rainfall in the austral summer associated with the South Atlantic Convergence Zone (SACZ) [58,59,63-65]. However, apart from the seasonal cycle, studies have shown that the SAMS also exhibit a strong intraseasonal modulation during the austral summer, which is characterized by two distinct phases: an active SACZ and an inactive SACZ [59,63]. During the active phase of SACZ, the diurnal cycle is weak and, although precipitation is abundant, it is mostly stratiform. In contrast, during the inactive phase of the SACZ, the diurnal cycle is stronger and precipitation occurs in the form of deep convection $[66,67]$. Therefore, windthrows appear to be associated with convective rainfall prevailing in the inactive phase of the SACZ during the austral summer. Furthermore, this convective precipitation associated with windthrow occurrence might be due to organized deep convection activity related to multicell storms that are part of squall lines, since ordinary or single cell storms are unlikely to yield strong gusty winds at the surface $[68,69]$. In particular, as previously discussed, squall systems embedded in environments with moderate or strong vertical shear in the lower troposphere are the mostly likely candidates to yield the observed windthrows, since the vertical shear in the lower troposphere enhances convective cells organization and, consequently, the intensity of downdrafts, making downbursts more likely [68,69]. This finding is supported by previous studies that examine windthrow formation in Amazonia $[1,3]$.

Regarding squall lines, NSLs are much more common in Amazonia than SSLs and have therefore been more extensively studied. However, SSLs are more frequent than their previously reported 40-50 year return period [23]. Our results suggest that SSLs that originate in southwestern Amazonia and propagate northeastward across the basin are more likely to occur during the wet season (Figure 6). Furthermore, these SSLs exhibit features typical of mid-latitude squall lines, which are usually generated in the front's warm sector hundreds of kilometers ahead of the surface cold front (Figures 7 and 8). In this context, these SSLs appear to be associated with a warm conveyor belt with forward lift that develops parallel to the cold front along the vanguard and propagates perpendicular to the cold front ahead of it. Therefore, one possible instability mechanism triggering SSLs may be the anomalous 
moisture convergence and conditional instability that results in deep convection formation in a band-like structure in the front's vanguard. This instability mechanism is similar to that responsible for triggering pre-frontal squall lines in the mid-latitudes [70-73] and requires both moisture convergence and a surface temperature gradient related to a frontogenic process [74]. The linear forcing mechanism that triggers these squall systems appears to be associated with a conditional symmetric instability related to anomalous frontogenesis development at latitudes around $15^{\circ} \mathrm{S}$ and $10^{\circ} \mathrm{S}$. The synoptic-scale flow regime associated with the propagation of the cold front toward the equator yields a directional lower troposphere vertical wind shear. This shear occurs perpendicular to the squall lines and is responsible for the propagation, organization, and longevity of these SSLs. Furthermore, like NSLs, SSLs can also interact with diurnally varying forcings along their trajectories over the Amazon basin, such as river breeze circulations. This interaction may enhance their amplitude at specific locations and times. A full investigation of all mechanisms triggering SSL formation, longevity, propagation and intensity is beyond the scope of this study.

We found that a large number of windthrows were observed even during years with low rainfall. This suggests that a higher temporal resolution analysis is needed to capture the types of systems producing intense rainfall and windthrows (Supplementary Materials Figure S1). Higher temporal and spatial rainfall data is needed. The TRMM3h data appear to be insufficient given that a system can cross the entire Landsat scene within the $3 \mathrm{~h}$ TRMM3h window. Furthermore, the spatial resolution of TRMM3h data $\left(0.25^{\circ}\right)$ is orders of magnitude larger than most frequent windthrows (range of 1 tree to 100 ha). The current Global Precipitation Measurement data (GPM) has a $30 \mathrm{~min}$ time step and $0.1^{\circ}$ resolution [75], which may help to provide more detailed analysis. However, even with the proper rainfall data, a constraint will remain due to the dating uncertainty of windthrows (Section 2.4) in long time series' across the entire Amazon.

ENSO $[58,63,76,77]$ affects the interannual variability of rainfall in the Amazon. During the El Niño (La Niña) phase of ENSO, there is a higher (lower) than average sea surface temperature in the equatorial Pacific ocean [26] which is associated with lower (higher) than average rainfall over Central Amazonia [26,78]. The decrease (increase) of rainfall during the El Niño (La Niña) is associated with the weakening (strengthening) of easterly circulation in the lower troposphere resulting in a decrease (increase) of humidity transport toward the Amazon, decreasing (increasing) the potential for convection. Though during some La Niña years we found a higher number of windthrows (Figure 5), we did not find an association between ENSO and windthrows. This may be related to the fact that the occurrence of extreme convective system does not follow the ENSO variability (Figure S1). We emphasize that, despite the increased convection during La Niña years, a longer time series is needed to establish an association between windthrows and ENSO. Though Landsat imagery are available since the 1970s, the TRMM3h data is only available since 1998 and the GPM data since 2014. TRMM3h together with the GPM and Landsat provide at best about 20 years of data, which may still not be enough for a rigorous statistical analysis of the association between windthrows and ENSO.

Long-lived northerly squall lines are associated with low level jets (LLJs), a phenomenon expected to be more frequent under a warming climate [79]. LLJs may also trigger SSLs, given that they are essential synoptic-scale features that propagate cold fronts toward Southeast Brazil. To our knowledge, current ESMs are unable to represent windthrows. However, changes in the frequency of windthrows are important within the context of forest shifts that will affect the terrestrial carbon budget, and, therefore, feedback with climate $[14,80]$. Thus, predicting the occurrence of the meteorological systems that produce windthrows holds important ecological consequences and may prevent fatalities [81] and economic losses [82] like those that occurred following the January 2005 SSL event [3].

It should be emphasized that the interaction of wind and trees is nonlinear and involves complex processes and the integration of disciplines such as soil science, physiology, ecology, biomechanics, and meteorology $[6,11,83,84]$. Wind, wind loading, gusts of winds, tree stature, tree species (and associated characteristics such as tree crown shape and density, root architecture and shape, and wood density), topography, soil, cumulative processes, etc. all play a role in the production of windthrows $[11,83-88]$ 
resulting in tree failure at a lower wind speed than expected [1,3]. Amazonia covers about 5.3 million $\mathrm{km}^{2}$, and has many environmental and functional gradients [89,90]. For instance, western Amazonia maintains higher rainfall and wood productivity compared with the long dry-season and less productive eastern Amazonia [89,91]. The environmental variability across the basin made it necessary to divide it into regions (e.g., $[10,92,93])$. The focus of our study is Central Amazonia because this area represents a large fraction of Amazonia. Identifying windthrows allowed us to discover a higher frequency of SSLs across the Amazon than previously reported. These squall lines have important implications not only for meteorology but also for disciplines like plant physiology and ecology. Our study provides a method that can easily be replicated in other areas of the Amazon to later integrate a basin wide perspective.

Some important aspects of the variability of windthrows remain unexplored due to limitations associated with image availability, resolution, and focus of this study. For instance, the monthly variability of windthrows will be an important factor in more closely linking windthrow occurrence and rainfall, especially due to the aforementioned intraseasonal modulation of the SAMS. A case by case study is needed to determine the atmospheric characteristics that cause downbursts and windthrows in Amazonia. The use of Landsat imagery limited the size of windthrows studied, and, therefore, the whole gradient of windthrow variability - from smaller windthrows $(<5$ ha) to more frequent windthrows (1 single windthrown trees)—remains to be studied. Furthermore, the tropical North Atlantic SST has a stronger influence over southern Amazonian rainfall during the dry season and when ENSO has limited activity (as in 2005 [39]), and the South Atlantic SST has limited influence on rainfall over the Atlantic coast of South America and the southern edge of the basin during the early dry season [94,95]. Thus, Atlantic SSTs mainly influence southern Amazonian rainfall where SSLs are formed, and, therefore, an association between Atlantic SSTs and windthrows should not be ruled out. However, to our knowledge, there are no studies addressing this association.

\section{Conclusions}

Our study shows that, although windthrows occur all year long, they have a seasonal and interannual variability driven by severe convective systems. The variability of windthrows is somewhat mirrored in the variability of annual rainfall. In general, a higher number of windthrows occurs during the rainy season (SONDJF). However, we did not find an association between windthrows and ENSO over the study period. Severe convective events associated with mesoscale convective systems, such as squall lines, drive the observed variability. We found that southerly squall lines have a higher frequency of occurrence and a greater effect on windthrows than previously reported. These systems deserve special attention given the large amount of rainfall they produce and their resulting ecological impacts. Because windthrows are an important driver of forest structure and dynamics, our study emphasizes the need to include windthrows in ESMs in order to reduce the uncertainties of climate predictions.

Supplementary Materials: The following are available online at www.mdpi.com/2073-4433/8/2/28/s1.

Acknowledgments: This research was supported as part of the Next Generation Ecosystem Experiments-Tropics and the Regional and Global Climate Modeling, both funded by the U.S. Department of Energy, Office of Science, and the Office of Biological and Environmental Research under contract DE-AC02-05CH11231. We thank Maria Assunção Faus da Silva Dias and Pedro Leite da Silva Dias of the University of Sao Paulo, Brazil and Julia Cohen of the Federal University of Para, Brazil for their valuable comments on southerly squall lines.

Author Contributions: R.N.-J. and H.S.J. conceived and designed the study; all authors analyzed the data; and all authors wrote the paper.

Conflicts of Interest: The authors declare no conflict of interest.

\section{References}

1. Garstang, M.; White, S.; Shugart, H.H.; Halverson, J. Convective cloud downdrafts as the cause of large blowdowns in the Amazon rainforest. Meteorol. Atmos. Phys. 1998, 67, 199-212. [CrossRef]

2. Fujita, T.T. The Downburst: Microburst and Macroburst; University of Chicago: Chicago, IL, USA, $1985 ;$ p. 122. 
3. Negrón-Juárez, R.I.; Chambers, J.Q.; Guimaraes, G.; Zeng, H.; Raupp, C.F.M.; Marra, D.M.; Ribeiro, G.H.P.M.; Saatchi, S.S.; Nelson, B.W.; Higuchi, N. Widespread Amazon forest tree mortality from a single cross-basin squall line event. Geophys. Res. Lett. 2010, 37, L16701. [CrossRef]

4. Nelson, B.W.; Kapos, V.; Adams, J.B.; Oliveira, W.; Braun, O. Forest disturbance by large blowdowns in the Brazilian Amazon. Ecology 1994, 75, 853-858. [CrossRef]

5. Espirito-Santo, F.D.B.; Keller, M.; Braswell, B.; Nelson, B.W.; Frolking, S.; Vicente, G. Storm intensity and old-growth forest disturbances in the Amazon region. Geophys. Res. Lett. 2010, 37, L11403. [CrossRef]

6. Mitchell, S.J. Wind as a natural disturbance agent in forests: A synthesis. Forestry 2013, 86, 147-157. [CrossRef]

7. Negrón-Juárez, R.I.; Chambers, J.Q.; Marra, D.M.; Ribeiro, G.H.P.M.; Rifai, S.W.; Higuchi, N.; Roberts, D. Detection of subpixel treefall gaps with Landsat imagery in Central Amazon forests. Remote Sens. Environ. 2011, 115, 3322-3328. [CrossRef]

8. Chambers, J.Q.; Negron-Juarez, R.I.; Marra, D.M.; Di Vittorio, A.; Tews, J.; Roberts, D.; Ribeiro, G.H.P.M.; Trumbore, S.E.; Higuchi, N. The steady-state mosaic of disturbance and succession across an old-growth Central Amazon forest landscape. Proc. Natl. Acad. Sci. USA 2013, 110, 3949-3954. [CrossRef] [PubMed]

9. Malhi, Y.; Doughty, C.; Goldsmith, G.; Metcalfe, D.B.; Girardin, C.A.J.; Marthews, T.R.; Del Aguila-Pasquel, J.; Aragao, L.E.; Brando, P.M.; Da Costa, A.L.; et al. The linkages between photosynthesis, productivity, growth and biomass in lowland Amazonian forests. Glob. Chang. Biol. 2015, 21, 2283-2295. [CrossRef] [PubMed]

10. Ter Steege, H.; Pitman, N.C.A.; Sabatier, D.; Baraloto, C.; Salomao, R.P.; Guevara, J.E.; Phillips, O.L.; Castilho, C.V.; Magnusson, W.E.; Molino, J.-F.; et al. Hyperdominance in the Amazonian tree Flora. Science 2013, 342, 1243092. [CrossRef] [PubMed]

11. Magnabosco Marra, D.; Chambers, J.Q.; Higuchi, N.; Trumbore, S.E.; Ribeiro, G.H.P.M.; dos Santos, J.; Negron-Juarez, R.I.; Reu, B.; Wirth, C. Large-scale wind disturbances promote tree diversity in a Central Amazon forest. PLoS ONE 2014, 9, e103711.

12. Chambers, J.Q.; Robertson, A.L.; Carneiro, V.M.C.; Lima, A.J.N.; Smith, M.-L.; Plourde, L.C.; Higuchi, N. Hyperspectral remote detection of niche partitioning among canopy trees driven by blowdown gap disturbances in the Central Amazon. Oecologia 2009, 160, 107-117. [CrossRef] [PubMed]

13. Dos Santos, L.T.; Magnabosco Marra, D.; Trumbore, S.; Camargo, P.B.; Chambers, J.Q.; Negron-Juarez, R.I.; Lima, A.J.N.; Ribeiro, G.H.P.M.; Dos Santos, J.; Higuchi, N. Windthrows increase soil carbon stocks in a Central Amazon forest. Biogeosci. Discuss 2015, 12, 19351-19372. [CrossRef]

14. Holm, J.A.; Chambers, J.; Collins, W.D.; Higuchi, N. Forest response to increased disturbance in the Central Amazon and comparison to Western Amazonian forests. Biogeosciences 2014, 11, 5773-5794. [CrossRef]

15. Intergovernmental Panel on Climate Change (IPCC). Climate Change 2013: The Physical Science Basis. Contribution of Working Group I to the Fifth Assessment Report of the Intergovernmental Panel on Climate Change; IPCC: Cambridge, UK, 2013; p. 1535.

16. Nelson, B.W.; Amaral, I. Destructive wind efects detected in tm images of the Amazon basin. In Proceedings of the International Society for Photogrammetry and Remote Sensing, Rio de Janeiro, Brazil, 26-30 September 1994; Brazil's National Institute for Space Research: Rio de Janeiro, Brazil, 1994; pp. 339-343.

17. Cohen, J.; Cavalcanti, I.F.A.; Braga, R.H.M.; Neto, S.L. Squall line in the N-NE coast of South America. In Weather and Climate of Brazil; Cavalcanti, I.F.A., Ferreira, N.J., Silva, M.G.A.J., Silva Dias, M.A.F., Eds.; Oficina de Textos: Sao Paulo, Brazil, 2009; pp. 75-93.

18. Greco, S.; Scala, J.; Halverson, J.; Massie, H.L.; Tao, W.K.; Garstang, M. Amazon coastal squall lines. 2. Heat and moisture transports. Mon. Weather Rev. 1994, 122, 623-635. [CrossRef]

19. Alcantara, C.R.; Silva Dias, M.A.F.; Souza, E.P.; Cohen, J.C.P. Verification of the role of the low level jets in Amazon squall lines. Atmos. Res. 2011, 100, 36-44. [CrossRef]

20. Cohen, J.; Dias, M.; Nobre, C.A. Environmental conditions associated with Amazonian squall lines. A case study. Mon. Weather Rev. 1995, 123, 3163-3174. [CrossRef]

21. Dias, M.; Ferreira, R.N. Application of a linear spectral model to the study of Amazonian squall lines during GTE ABLE 2B. J. Geophys. Res. Atmos. 1992, 97, 20405-20419. [CrossRef]

22. Cohen, J.; Silva Dias, M.A.F.; Nobre, C.A. Climatological aspect of Amazon squall lines. Climanalise Boletim de Monitoriamento e Analise Climatico 1989, 4, 34-40.

23. Molion, L.; Imbuzeiro, H.; Cavalcanti, I.F.A. Intense rainfalls in the east of Amazon: February of 1980. Climanal. J. 2006, 11, 20-27. (In Portuguese) 
24. Espinoza, J.C.; Ronchail, J.; Lengaigne, M.; Quispe, N.; Silva, Y.; Bettolli, M.L.; Avalos, G.; Llacza, A. Revisiting wintertime cold air intrusions at the east of the Andes: Propagating features from subtropical Argentina to Peruvian Amazon and relationship with large-scale circulation patterns. Clim. Dyn. 2013, 41, 1983-2002. [CrossRef]

25. Alonso, M.F.; Saraiva, J. Simulation of a squall line occurred in January 18th 2005. In Proceedings of the International Symposium on Nowcasting and Very Short Range Forecasting (WSN05), Toulouse, France, 5-9 September 2005.

26. Trenberth, K.E. El niño southern oscillation (ENSO). In Reference Module in Earth Systems and Environmental Sciences; Elsevier Ltd.: London, UK, 2013.

27. Andrade, E.A.; Higuchi, N. Productivity of four terra firme tree species of Central Amazonia. Acta Amazon. 2009, 39, 105-112. [CrossRef]

28. Ferraz, J.; Oht, S.; Salles, P.C. Distribuição dos solos ao longo de dois transectos em floresta primária ao norte de Manaus (AM). In Pesquisas Florestais Para a Conservação da Floresta e Reabilitação de Áreas Degradadas da Amazônia; Higuchi, N., Campos, M.A.A., Sampaio, P.T.B., Santos, J., Eds.; INPA: Manaus, Brazil, 1998; pp. 111-143.

29. Renno, C.D.; Nobre, A.D.; Cuartas, L.A.; Soares, J.V.; Hodnett, M.G.; Tomasella, J.; Waterloo, M.J. Hand, a new terrain descriptor using SRTM-DEM: Mapping terra-firme rainforest environments in Amazonia. Remote Sens. Environ. 2008, 112, 3469-3481. [CrossRef]

30. Luizao, R.C.C.; Luizao, F.J.; Paiva, R.Q.; Monteiro, T.F.; Sousa, L.S.; Kruijt, B. Variation of carbon and nitrogen cycling processes along a topographic gradient in a central amazonian forest. Glob. Chang. Biol. 2004, 10, 592-600. [CrossRef]

31. Carneiro, V.M.C.; Lima, A.J.N.; Pinto, A.C.; Santos, J.; Teixeira, L.M.; Higuchi, N. Floristic composition and structural analisis of terr firme forests in Manaus, Amazonas, Brazil. In V Congresso FlorestalNacional: A Floresta e as Gentes; Actas das Comunicações-Inventário, Modelação e Gestão: Viseu, Portugal, 2005; pp. 1-12.

32. Higuchi, N.; Dos Santos, J.; Ribeiro, R.J.; Freitas, J.V.; Vieira, G.; Cornic, A. Crescimento e Incremento de Uma Floresta Amazônica de Terra-Firme Manejada Experimentalmente; INPA: Manaus, Brazil, 1997; pp. 89-132.

33. Saito, S.; Sakai, T.; Nakamura, S.; Higuchi, N. Three types of seedling establishments of tree species in an Amazonian terra-firme forest. In Projeto Jacaranda Fase II: Pesquisas Florestais na Amazonia; Higuchi, N., Ed.; INPE: Manaus, Brazil, 2003; pp. 33-41.

34. Lima, A.J.N.; Teixeira, L.M.; Carneiro, V.M.C.; Santos, J.; Higuchi, N. Biomass stock and structural analysis of a secondary forest in Manaus (AM) region, ten years after clear cutting followed by fire. Acta Amazon. 2007, 37, 49-54.

35. Vieira, S.; de Camargo, P.B.; Selhorst, D.; da Silva, R.; Hutyra, L.; Chambers, J.Q.; Brown, I.F.; Higuchi, N.; dos Santos, J.; Wofsy, S.C.; et al. Forest structure and carbon dynamics in Amazonian tropical rain forests. Oecologia 2004, 140, 468-479. [CrossRef] [PubMed]

36. Higuchi, N.; Chambers, J.Q.; Santos, J.; Ribeiro, R.J.; Pinto, A.C.; Silva, R.P.; Rocha, R.M.; Tribuzy, E.S. Carbon balance and dynamics of primary vegetation in the Central Amazon. Floresta 2004, 34, 295-304.

37. Da Silva, R.P.; dos Santos, J.; Tribuzy, E.S.; Chambers, J.Q.; Nakamura, S.; Higuchi, N. Diameter increment and growth patterns for individual tree growing in Central Amazon, Brazil. For. Ecol. Manag. 2002, 166, 295-301. [CrossRef]

38. Higuchi, F.G.; Siqueira, J.D.P.; Lima, A.J.N.; Figueiredo, A.; Higuchi, N. The effect of plot size on the precision of the weibull distribution of diameters in the primary forest of the Central Amazon. FLORESTA 2012, 2, 599-606. [CrossRef]

39. Marengo, J.A.; Nobre, C.A.; Tomasella, J.; Oyama, M.D.; De Oliveira, G.S.; De Oliveira, R.; Camargo, H.; Alves, L.M.; Brown, I.F. The drought of Amazonia in 2005. J. Clim. 2008, 21, 495-516. [CrossRef]

40. Schneider, U.; Becker, A.; Finger, P.; Meyer-Christoffer, A.; Rudolf, B.; Ziese, M. GPCC Full Data Reanalysis Version 7.0 at $0.5^{\circ}$ : Monthly Land-Surface Precipitation from Rain-Gauges Built on GTS-Based and Historic Data; GPCC: Offenbach, Germany, 2015.

41. Harris, I.; Jones, P.D.; Osborn, T.J.; Lister, D.H. Updated high-resolution grids of monthly climatic observations-The CRU TS3.10 dataset. Int. J. Climatol. 2014, 34, 623-642. [CrossRef]

42. Sombroek, W. Spatial and temporal patterns of Amazon rainfall-Consequences for the planning of agricultural occupation and the protection of primary forests. Ambio 2001, 30, 388-396. [CrossRef] [PubMed] 
43. Huffman, G.J.; Adler, R.F.; Bolvin, D.T.; Gu, G.J.; Nelkin, E.J.; Bowman, K.P.; Hong, Y.; Stocker, E.F.; Wolff, D.B. The TRMM multisatellite precipitation analysis (TMPA): Quasi-global, multiyear, combined-sensor precipitation estimates at fine scales. J. Hydrometeorol. 2007, 8, 38-55. [CrossRef]

44. NCEP. National centers for environmental prediction. Available online: http://nomad3.Ncep.Noaa.Gov/ ncep_data/ (accessed on 1 December 2016).

45. Google Earth Engine Team (GEE). Google Earth Engine: A Planetary-Scale Geospatial Analysis Platform. 2015. Available online: https:/ / earthengine.Google.Com (accessed on 1 December 2015).

46. Adams, J.B.; Sabol, D.E.; Kapos, V.; Almeida, R.; Roberts, D.A.; Smith, M.O.; Gillespie, A.R. Classification of multispectral images based on fractions of endmembers-Application to land-cover change in the Brazilian Amazon. Remote Sens. Environ. 1995, 52, 137-154. [CrossRef]

47. Shimabukuro, Y.E.; Smith, J.A. The least-squares mixing models to generate fraction images derived from remote-sensing multispectral data. IEEE Trans. Geosci. Remote Sens. 1991, 29, 16-20. [CrossRef]

48. Adams, J.B.; Gillespie, A.R. Remote Sensing of Landscapes with Spectral Images: A Physical Modeling Approach; Cambridge University Press: Cambridge, UK, 2006.

49. Lu, D.; Batistella, M.; Moran, E.; Mausel, P. Application of spectral mixture analysis to Amazonian land-use and land-cover classification. Int. J. Remote Sens. 2004, 25, 5345-5358. [CrossRef]

50. Huang, B.Y.; Banzon, V.F.; Freeman, E.; Lawrimore, J.; Liu, W.; Peterson, T.C.; Smith, T.M.; Thorne, P.W.; Woodruff, S.D.; Zhang, H.M. Extended reconstructed sea surface temperature version 4 (ERSST.V4). Part I: Upgrades and intercomparisons. J. Clim. 2015, 28, 911-930. [CrossRef]

51. NOAA-CPC. National oceanic and atmospheric administration/national weather service/climate prediction center. Historical el niño/ la niña episodes (1950-present). Available online: http:/ /www.Cpc.Ncep.Noaa. Gov/products/analysis_monitoring/ensostuff/ensoyears.Shtml (accessed on 1 December 2016).

52. Marengo, J.A.; Tomasella, J.; Soares, W.R.; Alves, L.M.; Nobre, C.A. Extreme climatic events in the Amazon basin climatological and hydrological context of recent floods. Theor. Appl. Climatol. 2012, 107, 73-85. [CrossRef]

53. Climanalise-INPE. Brazil's National Institute for Space Research-Climanalise. January 2005. Available online: http:/ / climanalise.Cptec.Inpe.Br./ rclimanl/boletim/\# (accessed on 1 December 2016).

54. Kodama, Y. Large-scale common features of subtropical precipitation zones (the Baiu Frontal Zone, the SPCZ and the SACZ).1. Characteristics of subtropucal frontal zones. J. Meteorol. Soc. Jpn. 1992, 70, 813-836.

55. Liebmann, B.; Kiladis, G.N.; Marengo, J.A.; Ambrizzi, T.; Glick, J.D. Submonthly convective variability over South America and the South Atlantic convergence zone. J. Clim. 1999, 12, 1877-1891. [CrossRef]

56. Kodama, Y. Large-scale common features of subtropical precipitation zones (the Baiu Frontal Zone, the SPCZ and the SACZ). 2. Conditions of the circulations for generate the STCZs. J. Meteorol. Soc. Jpn. 1993, 71, 581-610.

57. Nunes, A.M.; Silva Dias, M.A.F.; Anselmo, E.M.; Morales, C.A. Severe convection features in the Amazon basin: A TRMM-based 15-year evaluation. Front. Earth Sci. 2016, 4, 37. [CrossRef]

58. Marengo, J.A.; Liebmann, B.; Grimm, A.M.; Misra, V.; Dias, P.L.S.; Cavalcanti, I.F.A.; Carvalho, L.M.V.; Berbery, E.H.; Ambrizzi, T.; Vera, C.S.; et al. Recent developments on the south American monsoon system. Int. J. Climatol. 2012, 32, 1-21. [CrossRef]

59. Jones, C.; Carvalho, L.M.V. Active and break phases in the South American monsoon system. J. Clim. 2002, 15, 905-914. [CrossRef]

60. Zhou, J.Y.; Lau, K.M. Does a monsoon climate exist over South America? J. Clim. 1998, 11, $1020-1040$. [CrossRef]

61. Da Silva, A.E.; Carvalho, L.M.V. Large-scale index for South America monsoon system (LISAM). Atmos. Sci. Lett. 2007, 8, 51-57. [CrossRef]

62. Liebmann, B.; Mechoso, C.R. The South American monsoon system. In The Global Monsoon System: Research and Forecast, 2nd ed.; Chang, C.P., Ding, Y., Lau, N.C., Johnson, R.H., Wang, B., Yasunari, T., Eds.; World Scientifc Publishing Co. Pte. Ltd.: Singapore, 2011; pp. 137-157.

63. Carvalho, L.M.V.; Jones, C.; Liebmann, B. The South Atlantic Convergence zone: Intensity, form, persistence, and relationships with intraseasonal to interannual activity and extreme rainfall. J. Clim. 2004, 17, 88-108. [CrossRef]

64. Robertson, A.W.; Mechoso, C.R. Interannual and interdecadal variability of the South Atlantic convergence zone. Mon. Weather Rev. 2000, 128, 2947-2957. [CrossRef] 
65. Carvalho, L.M.V.; Jones, C.; Liebmann, B. Extreme precipitation events in southeastern South America and large-scale convective patterns in the South Atlantic convergence zone. J. Clim. 2002, 15, 2377-2394. [CrossRef]

66. Anagnostou, E.N.; Morales, C.A. Rainfall estimation from TOGA radar observations during LBA field campaign. J. Geophys. Res. Atmos. 2002, 107, LBA 35-1-LBA 35-14. [CrossRef]

67. Albrecht, R.I.; Morales, C.A.; Dias, M. Electrification of precipitating systems over the Amazon: Physical processes of thunderstorm development. J. Geophys. Res. Atmos. 2011, 116. [CrossRef]

68. Weisman, M.L.; Klemp, J.B. The dependence of numerically simulated convective storms on vertical wind shear and buoyancy. Mon. Weather Rev. 1982, 110, 504-520. [CrossRef]

69. Rotunno, R.; Klemp, J.B. The influence of the shear-induced pressure-gradient on thunderstorm motion. Mon. Weather Rev. 1982, 110, 136-151. [CrossRef]

70. Bennetts, D.A.; Hoskins, B.J. Conditional symmetric instability-Possible explanation for frontal rainbands. Q. J. R. Meteorol. Soc. 1979, 105, 945-962. [CrossRef]

71. Emanuel, K.A. The lagrangian parcel dynamics of moist symmetric instability. J. Atmos. Sci. 1983, 40, 2368-2376. [CrossRef]

72. Emanuel, K. Inertial instability and mesoscale convective systems. 1. Linear-theory of inertial instability in rotating viscous fluids. J. Atmos. Sci. 1979, 36, 2425-2449. [CrossRef]

73. Xu, Q. Conditional symmetric instability and mesoscale rainbands. Q. J. R. Meteorol. Soc. 1986, 112, 315-334. [CrossRef]

74. Emanuel, K. Inertial instability and meososcale convective systems. 2. Symmetric cisk in a baroclinic flow. J. Atmos. Sci. 1982, 39, 1080-1097.

75. Hou, A.Y.; Kakar, R.K.; Neeck, S.; Azarbarzin, A.A.; Kummerow, C.D.; Kojima, M.; Oki, R.; Nakamura, K.; Iguchi, T. The global precipitation measurement mission. Bull. Am. Meteorol. Soc. 2014, 95, 701-722. [CrossRef]

76. Nobre, C.A.; Obregon, G.; Marengo, J.A.; Fu, R.; Poveda, G. Characteristics of Amazonian climate: Main features. In Amazonia and Global Change; Keller, M., Bustamante, M., Gash, J., Silva Dias, P., Eds.; American Geophysical Union: Washington, DC, USA, 2009; pp. 149-162.

77. Marengo, J.A.; Espinoza, J.C. Extreme seasonal droughts and floods in Amazonia: Causes, trends and impacts. Int. J. Climatol. 2016, 36, 1033-1050. [CrossRef]

78. Espinoza Villar, J.C.; Ronchail, J.; Guyot, J.L.; Cochonneau, G.; Naziano, F.; Lavado, W.; De Oliveira, E.; Pombosa, R.; Vauchel, P. Spatio-temporal rainfall variability in the Amazon basin countries (Brazil, Peru, Bolivia, Colombia, and Ecuador). Int. J. Climatol. 2009, 29, 1574-1594. [CrossRef]

79. Marengo, J.A.; Nobre, C.A.; Betts, R.A.; Cox, P.M.; Sampaio, G.; Salazar, L. Global warming and climate change in Amazonia: Climate-vegetation feedback and impacts on water resources. Amazon. Glob. Chang. 2009, 186, 273-292.

80. Trumbore, S.; Brando, P.; Hartmann, H. Forest health and global change. Science 2015, 349, $814-818$. [CrossRef] [PubMed]

81. Folha. Rainfall killed 4 and evacuate 1145 in the country. Folha de Sao Paulo, 18 January 2005; C3.

82. Folha. Rainfall produce damage in three states. Folha de Sao Paulo, 20 January 2005; C3.

83. Quine, C.P.; Gardiner, B.A. Understanding how the interaction of wind and trees results in windthrow, stem breakage, and canopy gap formation. In Plant Disturbance Ecology. The Process and the Response, 1st ed.; Johnson, E.A., Miyanishi, K., Eds.; Academic Press: Burlington, MA, USA, 2007; pp. 103-155.

84. Negrón-Juárez, R.I.; Chambers, J.; Hurtt, G.; Annane, B.; Cocke, S.; Powell, M.; Stott, M.; Goosem, S.; Metcalfe, D.; Saatchi, S. Remote sensing assessment of forest disturbance across complex mountainous terrain: The pattern and severity of impacts of tropical cyclone Yasi on Australian rainforests. Remote Sens. 2014, 6, 5633-5649. [CrossRef]

85. Negrón-Juárez, R.I.; Baker, D.B.; Chambers, J.Q.; Hurtt, G.C.; Goosem, S. Multi-scale sensitivity of landsat and modis to forest disturbance associated with tropical cyclones. Remote Sens. Environ. 2014, 140, 679-689. [CrossRef]

86. Coder, K.D. Trees and Storm Wind Load; University of Georgia: Athens, GA, USA, 2014; pp. 1-36.

87. Schindler, D.; Bauhus, J.; Mayer, H. Wind effects on trees. Eur. J. For. Res. 2012, 131, 159-163. [CrossRef]

88. England, A.H.; Baker, C.J.; Saunderson, S.E.T. A dynamic analysis of windthrow of trees. Forestry 2000, 73, 225-237. [CrossRef] 
89. Malhi, Y.; Davidson, E.A. Biogeochemestry and ecology of terrestrial ecosystem of Amazonia. In Amazonia and Global Change; Keller, M., Bustamante, M., Gash, J., Silva Dias, P., Eds.; American Geophysical Union: Washington, DC, USA, 2009; pp. 293-297.

90. Davidson, E.A.; de Araujo, A.C.; Artaxo, P.; Balch, J.K.; Brown, I.F.; MM, C.B.; Coe, M.T.; DeFries, R.S.; Keller, M.; Longo, M.; et al. The Amazon basin in transition. Nature 2012, 481, 321-328. [CrossRef] [PubMed]

91. Negrón-Juárez, R.I.; da Rocha, H.R.; e Figueira, A.M.S.; Goulden, M.L.; Miller, S.D. An improved estimate of leaf area index based on the histogram analysis of hemispherical photographs. Agric. For. Meteorol. 2009, 149, 920-928. [CrossRef]

92. Saleska, S.; Rocha, H.; Kruijt, B.; Nobre, A. Ecosystem carbon fluxes and Amazonian forest metabolism. In Amazonia and Global Change; Keller, M., Bustamante, M., Gash, J., Silva Dias, P., Eds.; American Geophysical Union: Washington, DC, USA, 2009; pp. 389-407.

93. Nobre, C.A.; Wickland, D.; Kabat, P. Large scale biosphere-atmosphere experiment in Amazonia (LBA). Glob. Chang. Newsl. 2001, 45, 2-4.

94. Yoon, J.-H.; Zeng, N. An atlantic influence on Amazon rainfall. Clim. Dyn. 2010, 34, 249-264. [CrossRef]

95. Ronchail, J.; Cochonneau, G.; Molinier, M.; Guyot, J.L.; Chaves, A.G.D.; Guimaraes, V.; de Oliveira, E. Interannual rainfall variability in the Amazon basin and sea-surface temperatures in the equatorial Pacific and the tropical Atlantic Oceans. Int. J. Climatol. 2002, 22, 1663-1686. [CrossRef]

(C) 2017 by the authors; licensee MDPI, Basel, Switzerland. This article is an open access article distributed under the terms and conditions of the Creative Commons Attribution (CC BY) license (http:/ / creativecommons.org/licenses/by/4.0/). 